\title{
GMR
}

\section{Genetic diversity among cotton cultivars in two environments in the State of Mato Grosso}

\author{
I.G. Santos ${ }^{1}$, P.E. Teodoro ${ }^{1,2}$, F.C. Farias ${ }^{3}$, F.J.C. Farias ${ }^{4}$, L.P. Carvalho ${ }^{4}$, \\ J.I.S. Rodrigues ${ }^{4}$ and C.D. Cruz ${ }^{1}$ \\ ${ }^{1}$ Departamento de Biologia Geral, Universidade Federal de Viçosa, Viçosa, \\ MG, Brasil \\ ${ }^{2}$ Departamento de Agronomia, Universidade Federal do Mato Grosso do Sul, \\ Chapadão do Sul, MS, Brasil \\ ${ }^{3}$ Escola de Agronomia, Universidade Federal de Goiás, Goiânia, GO, Brasil \\ ${ }^{4}$ Centro Nacional de Pesquisa de Algodão, Embrapa Algodão, Campina Grande, \\ PB, Brasil
}

Corresponding author: P.E. Teodoro

E-mail: eduteodoro@hotmail.com

Genet. Mol. Res. 16 (2): gmr16029628

Received January 26, 2017

Accepted February 23, 2017

Published April 13, 2017

DOI http://dx.doi.org/10.4238/gmr16029628

Copyright $(2017$ The Authors. This is an open-access article distributed under the terms of the Creative Commons Attribution ShareAlike (CC BY-SA) 4.0 License.

\begin{abstract}
Using commercial cultivars to compose crossing blocks in cotton is a promising strategy, because these materials have desirable agronomic and technological characteristics. The objective of this study was to evaluate the genetic diversity among 16 cotton cultivars cultivated in two environments in the State of Mato Grosso, the largest national producer, using agronomical and technological traits. There was significant effect to cultivars for all traits, while genotype $\mathrm{x}$ environment interaction was significant only for average boll weight, short fiber index, and maturity of fibers. Therefore, because of the presence of genotype $\mathrm{x}$ environment interaction for three traits, we chose to study genetic diversity among cotton cultivars separately in each environment and investigate the interaction impact on the diversity among genotype pairs. Based on agronomical and
\end{abstract}

Genetics and Molecular Research 16 (2): gmr16029628 
technological performance and genetic diversity among cultivars in both environments, the most promising cross involves FM 910 and LD CV 02. We also observed that lint percentage and average boll weight presented a higher discrimination capacity in both environments.

Key words: Agronomic traits; Technological traits; Gossypium hirssutum; Genotype $\mathrm{x}$ environment interaction

\section{INTRODUCTION}

Upland cotton (Gossypium hirssutum L.r. latifolium Hutch.) produces one of the most important textile fibers of the world and has been considered one of the main economically crops in Brazil (Carvalho et al., 2015a). In the world, Brazil is the fifth larger producer of seed cotton, with 4.4 million tons in the harvest of 2013/2014 (CONAB - Companhia Nacional de Abastecimento, 2015). The State of Mato Grosso is the largest national producer primarily in the municipalities of Primavera do Leste, Lucas do Rio Verde, and Sapezal (CONAB Companhia Nacional de Abastecimento, 2015; Farias et al., 2016).

Cotton-breeding process is dynamic and involves crosses and selections generally made within a restricted set of genetic variability, leading to a genetic diversity loss through limited allelic variability with consequent selection gain restrictions (Tyagi et al., 2014). Although the Gossypium genus is represented by 50 species, diploids $(2 \mathrm{n}=2 \mathrm{x}=26)$ and allotetraploids $(2 \mathrm{n}=4 \mathrm{x}=52), 90 \%$ of world cotton production has been coming of $G$. hirsutum because of its favorable characteristics (Tyagi et al., 2014; Hinze et al., 2016).

It is possible to maximize exploration of heterosis and to obtain segregant populations with the possibility of appearance of transgressive individuals, from the formation of a diversified base population with a satisfactory agronomic performance (Cruz et al., 2011, 2012). Among the available germplasm to carry out hybridizations in cotton, using commercial cultivars as genitors is the most promising strategy because these materials have desirable agronomic and technological characteristics; in other words, they have a high frequency of favorable alleles.

Aiming to identify promising crosses for the State of Mato Grosso, the objective of this study was to evaluate the genetic diversity among 16 cotton cultivars evaluated in two environments in the State of Mato Grosso.

\section{MATERIAL AND METHODS}

Two trials with upland cotton genotypes were conducted during the harvest 2008/2009 in the State of Mato Grosso in the following municipalities: Lucas do Rio Verde and Sapezal. The experimental design adopted consisted of a randomized compete block with 16 treatments (BRS ARAÇA, BRS BURITI, BRS 286, FMT 701, FM 993, FM 910, DELTA OPAL, IPR JATAI, LD CV 05, LD CV 02, BRS CEDRO, NUOPAL, CNPA MT 05 1245, CNPA MT 04 2080, CNPA MT 04 2088, and BRS 293) with four replicates each. The culture practices were the ones commonly used for growing cotton, including the use of herbicides for weed control and pest control, according to the integrated management of pests recommended for crop in the region.

The experimental unit consisted of four 5.0-m long rows, spaced at $0.90 \mathrm{~m}$, and at a density of 9 plants per $\mathrm{m}^{2}$. The agronomic traits evaluated were: plant height $(\mathrm{cm})$, average

Genetics and Molecular Research 16 (2): gmr16029628 
boll weight (g), lint percentage (\%), and cotton seed yield ( $\mathrm{kg} / \mathrm{ha})$. Twenty bolls from each experimental unit were evaluated for the following technological fiber traits: fiber length $(\mathrm{mm})$, short fiber index (\%), fiber strength (gf/tex), elongation (\%), micronaire (mg/inches), reflectance (\%), degree of yellowing, spinning, and maturity of fibers (\%) using the highvolume instrument from the Laboratory of Fibers of the Embrapa Algodão.

Firstly, univariate analysis of variance was performed for each trait and after detecting that the relationship between the largest and smallest residual mean squares of individual analysis of variance did not exceed the ratio 7:1 (Pimentel-Gomes, 2009), joint analysis of variance was carried out, considering the effects of genotypes as fixed and environments as random, according the following Equation 1:

$$
Y_{i j k}=\mu+B / E_{j k}+G_{i}+E_{j}+G E_{i j}+e_{i j k}
$$

where $\mathrm{Y}_{\mathrm{ijk}}$ is the genotype value of the $k$-th block, evaluated in the $i$-th genotype and $j$-th environment; $\mu$ is the overall average of the trials; $\mathrm{B} / \mathrm{E}_{\mathrm{jk}}$ is the effect of the block $k$ within the environment $j ; \mathrm{G}_{\mathrm{i}}$ is the effect of the $i$-th genotype; $\mathrm{E}_{\mathrm{j}}$ is the effect of the $j$-th environment; $\mathrm{GE}_{\mathrm{i}}$ is the effect of the interaction of genotype $i$ with the environment $j$; $\mathrm{e}_{\mathrm{ijk}}$ is the experimental error associated with observation $\mathrm{Y}_{\mathrm{ijk}}$, with $\mathrm{e}_{\mathrm{ijk}} \sim N\left(0 ; \mathrm{s}^{2}\right)$. The cultivar averages in relation to all the traits were cluster using the Skott-Knott criterion at 5\% probability.

For genetic diversity analysis, the genetic distance between different pairs of genotypes was calculated, for each environment, employing the generalized Mahalanobis distance $\left(\mathrm{D}_{\mathrm{ij}}{ }^{2}\right)$. Dissimilarities between genotype pairs, estimated in each environment, were compared by the Mantel correlation test based on 5000 permutations. Thereafter, Tocher optimization method was used to cluster the cultivars based on the criterion that the intragroup is smaller than the intergroup distances (Cruz et al., 2011). The relative contribution of traits to genetic diversity was evaluated according to the criterion described by Singh (1981).

All statistical analyses were performed using the GENES software (Cruz, 2013).

\section{RESULTS AND DISCUSSION}

\section{Joint analysis of variance and cultivar performance}

There were significant effects $(\mathrm{P}<0.05)$ among cotton cultivars for all traits (Table 1$)$, with the exception of fiber strength and short fiber index. Thus, for each significant trait there is at least a contrast between averages different from zero, revealing the cultivars potential for genetic diversity studies. The coefficients of variation were lower than $20 \%$ for all traits, similar to those obtained in other studies with the cotton crop (Freitas et al., 2007; Araújo et al., 2013; Carvalho et al., 2015a,b).

It is important to emphasize that there was significant genotype $\mathrm{x}$ environment interaction (GxE) only for average boll weight, short fiber index, and maturity of fibers. Similar results were observed by Carvalho et al. (2015b), when evaluating 36 cotton elite inbred lines in three environments did not observed GxE interaction for all agronomical and technological traits evaluated. Because of the presence of GxE interaction for three traits, we chose to study the genetic diversity among cotton cultivars separately in each environment and investigate the interaction impact on the diversity among genotype pairs.

Genetics and Molecular Research 16 (2): gmr16029628 
Table 1. Summary of joint analysis of variance for plant height $(\mathrm{PH}, \mathrm{cm})$, average boll weight (ABW, g), lint percentage (LP, \%), seed cotton yield (SCY, $\mathrm{kg} / \mathrm{ha}$ ), fiber length (FL, mm), short fiber index (SFI, \%), fiber strength (FS, gf/tex), elongation (EL, \%), micronaire (MIC, mg/inches), reflectance (REF, \%), degree of yellowing (B+), spinning (SPI), and maturity of fibers (MAT, \%) evaluated in 16 cotton cultivars in two environments in the State of Mato Grosso, Brazil.

\begin{tabular}{l|c|c|c|c|c|c|c|c}
\hline Sources of variation & d.f. & PH & ABW & LP & SCY & FL & SFI & FS \\
\hline Genotypes (G) & 15 & $259.31^{* *}$ & $0.73^{* *}$ & $15.28^{* *}$ & $1161317.24^{* *}$ & $2.96^{* *}$ & $0.36^{\text {ns }}$ & $5.81^{\text {ns }}$ \\
\hline Environments (E) & 1 & $1411.13^{\text {ns }}$ & $7.65^{* *}$ & $7.86^{*}$ & $137245977.71^{*}$ & $23.32^{* *}$ & $45.72^{* *}$ & $2.42^{\text {ns }}$ \\
\hline GxE & 15 & $34.25^{\text {ns }}$ & $3.06^{* *}$ & $0.34^{\text {ns }}$ & $345017.90^{\text {ns }}$ & $0.40^{\text {ns }}$ & $0.99^{* *}$ & $4.15^{\text {ns }}$ \\
\hline Mean & -- & 117.88 & 6.08 & 43.6 & 4293.75 & 30.61 & 5.49 & 30.31 \\
\hline CV $(\%)$ & -- & 4.72 & 4.53 & 1.47 & 15.26 & 2.09 & 11.91 & 5.37 \\
\hline Sources of variation & d.f. & EL & MIC & REF & B & SPI & MAT & \\
\hline Genotypes (G) & 15 & $1.47^{* *}$ & $0.34^{* *}$ & $7.06^{*}$ & $0.94^{* *}$ & $188.20^{*}$ & $3.68^{* *}$ & \\
\hline Environments (E) & 1 & $32.91^{* *}$ & $4.31^{* *}$ & $19.45^{\text {ns }}$ & $0.63^{\text {ns }}$ & $5163.82^{* *}$ & $78.13^{* *}$ & \\
\hline G xE & 15 & $0.37^{\text {ns }}$ & $0.06^{\text {ns }}$ & $2.02^{\text {ns }}$ & $0.10^{\text {ns }}$ & $72.39^{\text {ns }}$ & $1.01^{* *}$ & \\
\hline Mean & -- & 7.03 & 4.68 & 77.41 & 7.22 & 150.73 & 86.34 & \\
\hline CV $(\%)$ & -- & 6.65 & 4.53 & 1.95 & 4.88 & 5.34 & 0.73 &
\end{tabular}

ns** and *Not significant, significant according to the F-test at the 0.05 and 0.01 probability level, respectively; CV: coefficient of variation; d.f.: degrees of freedom.

In order to choose the most promising crosses, besides the presence of genetic diversity among the cultivars, it is necessary satisfactory agronomic performance (Cruz, 2012). Then, genotype averages were compared to orient the most promising crosses (Table 2). For traits in which significant $\mathrm{GxE}$ interaction was detected, the average comparison was done for each environment.

Table 2. Mean values for plant height (PH, cm), average boll weight (ABW, g), lint percentage ( $\mathrm{LP}, \%)$, seed cotton yield (SCY, kg/ha), fiber length (FL, mm), short fiber index (SFI, \%), fiber strength (FS, gf/tex), elongation (EL, $\%$ ), micronaire (MIC, mg/inches), reflectance (REF, \%), degree of yellowing (B+), spinning (SPI), and maturity of fibers (MAT, \%) evaluated in 16 cotton cultivars in two environments in the State of Mato Grosso, Brazil.

\begin{tabular}{|c|c|c|c|c|c|c|c|c|c|c|c|c|c|c|c|c|c|}
\hline \multirow[t]{2}{*}{ Genotypes } & \multirow[t]{2}{*}{ Id } & \multirow[t]{2}{*}{ PH } & \multicolumn{2}{|c|}{ ABW } & \multirow[t]{2}{*}{ LP } & \multirow[t]{2}{*}{ SCY } & \multirow[t]{2}{*}{ FL } & \multicolumn{2}{|c|}{ SFI } & \multirow[t]{2}{*}{ FS } & \multirow{2}{*}{ EL } & \multirow[t]{2}{*}{ MIC } & \multirow{2}{*}{ REF } & \multirow[t]{2}{*}{$\mathrm{B}+$} & \multirow[t]{2}{*}{ SPI } & \multicolumn{2}{|c|}{ MAT } \\
\hline & & & LRV & SPH & & & & LRV & SPH & & & & & & & LRV & $\mathrm{SPH}$ \\
\hline$\overline{\text { BRS ARACA }}$ & 1 & $113.25 \mathrm{~b}$ & $5.98 \mathrm{a}$ & $6.39 \mathrm{~b}$ & $41.73 \mathrm{~d}$ & $4608.88 \mathrm{~b}$ & $31.24 \mathrm{a}$ & $5.80 \mathrm{~b}$ & $4.73 \mathrm{~b}$ & $30.19 \mathrm{a}$ & $7.48 \mathrm{a}$ & $4.51 \mathrm{~b}$ & $77.30 \mathrm{a}$ & $7.53 \mathrm{a}$ & $153.00 \mathrm{a}$ & $86.25 \mathrm{c}$ & $85.00 \mathrm{c}$ \\
\hline BRS BURITI & 2 & $122.25 \mathrm{~b}$ & $6.14 \mathrm{a}$ & $6.20 \mathrm{c}$ & $42.28 \mathrm{c}$ & $5028.28 \mathrm{a}$ & $31.43 \mathrm{a}$ & $5.75 \mathrm{~b}$ & $5.15 \mathrm{a}$ & $29.86 \mathrm{a}$ & $6.33 \mathrm{~b}$ & $4.74 \mathrm{a}$ & $76.95 \mathrm{a}$ & $7.26 \mathrm{~b}$ & $151.38 \mathrm{a}$ & $88.25 \mathrm{a}$ & $86.00 \mathrm{~b}$ \\
\hline BRS 286 & 3 & $116.88 \mathrm{~b}$ & $5.74 \mathrm{~b}$ & $6.17 \mathrm{c}$ & $43.56 \mathrm{~b}$ & $3929.96 \mathrm{c}$ & $30.29 \mathrm{~b}$ & $5.83 \mathrm{~b}$ & $4.93 \mathrm{a}$ & $29.08 \mathrm{a}$ & $7.18 \mathrm{a}$ & $4.38 \mathrm{~b}$ & $76.33 \mathrm{~b}$ & $7.08 \mathrm{~b}$ & $148.38 \mathrm{a}$ & $85.75 \mathrm{c}$ & $85.00 \mathrm{c}$ \\
\hline FMT 701 & 4 & $118.13 \mathrm{~b}$ & $5.44 \mathrm{~b}$ & $6.66 \mathrm{a}$ & $43.94 \mathrm{~b}$ & $4183.22 \mathrm{~b}$ & $30.13 \mathrm{~b}$ & $6.88 \mathrm{a}$ & $4.38 \mathrm{~b}$ & $31.48 \mathrm{a}$ & $6.40 \mathrm{~b}$ & $5.05 \mathrm{a}$ & $78.53 \mathrm{a}$ & $6.86 \mathrm{~b}$ & $151.25 \mathrm{a}$ & $88.00 \mathrm{a}$ & $87.50 \mathrm{a}$ \\
\hline FM 993 & 5 & $116.63 \mathrm{~b}$ & $5.56 \mathrm{~b}$ & $6.21 \mathrm{c}$ & $44.71 \mathrm{a}$ & $4469.40 \mathrm{~b}$ & $31.08 \mathrm{a}$ & $6.93 \mathrm{a}$ & $4.75 \mathrm{~b}$ & $31.63 \mathrm{a}$ & $6.30 \mathrm{~b}$ & $4.75 \mathrm{a}$ & $78.44 \mathrm{a}$ & $6.95 \mathrm{~b}$ & $153.75 \mathrm{a}$ & $87.50 \mathrm{a}$ & $86.50 \mathrm{~b}$ \\
\hline FM 910 & 6 & $116.38 \mathrm{~b}$ & $5.07 \mathrm{~b}$ & $5.85 \mathrm{~d}$ & $45.01 \mathrm{a}$ & $4405.94 \mathrm{~b}$ & $31.91 \mathrm{a}$ & $5.50 \mathrm{~b}$ & $5.58 \mathrm{a}$ & $30.60 \mathrm{a}$ & $6.79 \mathrm{~b}$ & $4.70 \mathrm{a}$ & $78.79 \mathrm{a}$ & $6.79 \mathrm{~b}$ & $157.38 \mathrm{a}$ & $87.50 \mathrm{a}$ & $86.00 \mathrm{~b}$ \\
\hline DELTA OPAL & 7 & $116.38 \mathrm{~b}$ & $5.90 \mathrm{a}$ & $6.21 \mathrm{c}$ & $43.00 \mathrm{c}$ & $4071.62 \mathrm{~b}$ & $30.73 \mathrm{a}$ & $6.48 \mathrm{a}$ & $4.98 \mathrm{a}$ & $31.51 \mathrm{a}$ & $6.98 \mathrm{a}$ & $4.66 \mathrm{a}$ & $77.09 \mathrm{a}$ & $7.23 \mathrm{~b}$ & $154.50 \mathrm{a}$ & $87.75 \mathrm{a}$ & $85.25 \mathrm{c}$ \\
\hline IPR JATAI & 8 & $116.63 \mathrm{~b}$ & $6.58 \mathrm{a}$ & $6.88 \mathrm{a}$ & $42.89 \mathrm{c}$ & $4213.97 \mathrm{~b}$ & $30.61 \mathrm{~b}$ & $5.58 \mathrm{~b}$ & $4.75 \mathrm{~b}$ & $30.14 \mathrm{a}$ & $7.61 \mathrm{a}$ & $4.74 \mathrm{a}$ & $77.15 \mathrm{a}$ & $7.31 \mathrm{~b}$ & $152.25 \mathrm{a}$ & $87.00 \mathrm{~b}$ & $85.25 \mathrm{c}$ \\
\hline LD CV 05 & 9 & $119.13 \mathrm{~b}$ & $5.83 \mathrm{a}$ & $6.66 \mathrm{a}$ & $44.03 \mathrm{~b}$ & $4652.16 \mathrm{~b}$ & $29.91 \mathrm{~b}$ & $6.55 \mathrm{a}$ & $4.18 \mathrm{~b}$ & $30.61 \mathrm{a}$ & $7.34 \mathrm{a}$ & $4.93 \mathrm{a}$ & $77.94 \mathrm{a}$ & $6.89 \mathrm{~b}$ & $148.50 \mathrm{a}$ & $87.75 \mathrm{a}$ & $86.00 \mathrm{~b}$ \\
\hline LD CV 02 & 10 & $106.00 \mathrm{~b}$ & $6.17 \mathrm{a}$ & $6.72 \mathrm{a}$ & $41.37 \mathrm{~d}$ & $3316.31 \mathrm{c}$ & $30.35 \mathrm{~b}$ & $5.80 \mathrm{~b}$ & $4.75 \mathrm{~b}$ & $29.44 \mathrm{a}$ & $7.11 \mathrm{a}$ & $4.79 \mathrm{a}$ & $77.13 \mathrm{a}$ & $6.79 \mathrm{~b}$ & $147.38 \mathrm{a}$ & $86.00 \mathrm{c}$ & $86.00 \mathrm{~b}$ \\
\hline BRS CEDRO & 11 & $134.00 \mathrm{a}$ & $6.13 \mathrm{a}$ & $6.41 \mathrm{~b}$ & $44.59 \mathrm{a}$ & $4608.42 \mathrm{~b}$ & $30.38 \mathrm{~b}$ & $5.65 \mathrm{~b}$ & $5.20 \mathrm{a}$ & $30.61 \mathrm{a}$ & $6.90 \mathrm{~b}$ & $4.76 \mathrm{a}$ & $75.83 \mathrm{~b}$ & $7.63 \mathrm{a}$ & $150.13 \mathrm{a}$ & $87.50 \mathrm{a}$ & $85.75 \mathrm{~b}$ \\
\hline NUOPAL & 12 & $113.38 \mathrm{~b}$ & $5.58 \mathrm{~b}$ & $5.91 \mathrm{~d}$ & $41.40 \mathrm{~d}$ & $4098.06 \mathrm{~b}$ & $30.96 \mathrm{a}$ & $6.33 \mathrm{a}$ & $4.80 \mathrm{~b}$ & $29.83 \mathrm{a}$ & $6.76 \mathrm{~b}$ & $4.36 \mathrm{~b}$ & $78.29 \mathrm{a}$ & $7.28 \mathrm{~b}$ & $153.38 \mathrm{a}$ & $86.75 \mathrm{~b}$ & $84.75 \mathrm{c}$ \\
\hline CNPA MT 051245 & 13 & $117.50 \mathrm{~b}$ & $5.81 \mathrm{a}$ & $5.74 \mathrm{~d}$ & $43.42 \mathrm{~b}$ & $4149.64 \mathrm{~b}$ & $30.32 \mathrm{~b}$ & $6.25 \mathrm{a}$ & $5.33 \mathrm{a}$ & $30.58 \mathrm{a}$ & $7.15 \mathrm{a}$ & $4.39 \mathrm{~b}$ & $76.33 \mathrm{~b}$ & $7.94 \mathrm{a}$ & $149.63 \mathrm{a}$ & $86.25 \mathrm{c}$ & $84.75 \mathrm{c}$ \\
\hline CNPA MT 042080 & 14 & $120.88 \mathrm{~b}$ & $5.57 \mathrm{~b}$ & $6.38 \mathrm{~b}$ & $45.56 \mathrm{a}$ & $4436.06 \mathrm{~b}$ & $29.88 \mathrm{~b}$ & $6.18 \mathrm{a}$ & $4.68 \mathrm{~b}$ & $29.76 \mathrm{a}$ & $7.20 \mathrm{a}$ & $4.65 \mathrm{a}$ & $77.89 \mathrm{a}$ & $7.03 \mathrm{~b}$ & $147.63 \mathrm{a}$ & $87.00 \mathrm{~b}$ & $85.00 \mathrm{c}$ \\
\hline CNPA MT 042088 & 15 & $119.88 \mathrm{~b}$ & $5.91 \mathrm{a}$ & $6.26 \mathrm{c}$ & $45.16 \mathrm{a}$ & $4139.55 \mathrm{~b}$ & $30.77 \mathrm{a}$ & $5.70 \mathrm{~b}$ & $4.88 \mathrm{a}$ & $30.98 \mathrm{a}$ & $7.46 \mathrm{a}$ & $4.56 \mathrm{~b}$ & $78.39 \mathrm{a}$ & $7.24 \mathrm{~b}$ & $156.63 \mathrm{a}$ & $86.75 \mathrm{~b}$ & $84.75 \mathrm{c}$ \\
\hline BRS 293 & 16 & $118.88 \mathrm{~b}$ & $6.04 \mathrm{a}$ & $6.64 \mathrm{a}$ & 44.98 a & $4388.49 \mathrm{~b}$ & $29.69 \mathrm{~b}$ & $6.30 \mathrm{a}$ & & $28.73 \mathrm{a}$ & $7.56 \mathrm{a}$ & $4.98 \mathrm{a}$ & $76.20 \mathrm{a}$ & $7.70 \mathrm{a}$ & $136.50 \mathrm{~b}$ & $88.00 \mathrm{a}$ & $85.50 \mathrm{c}$ \\
\hline
\end{tabular}
Genotype identification. LRV = Lucas do Rio Verde; SPH = Spezal.

Plant height is the most important trait affecting the cotton harvest (Silva et al., 2011) because the harvester platform has a fixed size and plants of cultivars with plant height higher than $130 \mathrm{~cm}$, such as BRS CEDRO, can be tipped and kneaded by machine, reducing the quality and quantity of harvested fiber. Average boll weight is one of the main components of cotton plume production, relating linearly with lint percentage (Carvalho et al., 2005). Despite GxE interaction was detected for this trait, the cultivars IPR JATAI, LD CV 05, LD CV 02, and BRS 293 deserve mention because they presented the highest averages in both environments.

Genetics and Molecular Research 16 (2): gmr16029628 
Lint percent is estimated by the ratio between the weight of cotton in lint and the weight of cotton in seed and indicates how much of the total weight can be attributed to the fiber. This trait is fundamental to the farmer, because it is the part of commercialized production with higher economic value (Carvalho et al., 2005). There is a negative correlation between percentage of fibers and fiber length in long fiber materials (Carvalho et al., 2015a). However, in this study, we were able to identify two cultivars and one advanced line that presented the highest averages to lint percentage and fiber length besides the high productivity: FM 993, FM 910, and CNPA MT 04 2088. These results are interesting because using these selected genotypes in hybridizations we can contribute to increase lint percentage and fiber length values.

Short fiber index is directly related to fiber quality and processing. Although GxE interaction has not been significant for this trait, it was possible to identify genotypes with low values in both environments: BRS ARAÇA, IPR JATAI, and LD CV 02. These genotypes also presented the highest averages for elongation, in other words, they have fibers with higher strength and suffer less damage during processing. Even though there were no differences among cultivar averages to fiber strength, it is important to mention that all these cultivars had high fiber strength according to Santana et al. (2008).

Considering the traits micronaire, reflectance, and spinning, all cultivars presented adequate averages for processing by textile industry. Degree of yellowing indicates the degree of color pigmentation and all tested cultivars obtained acceptable values by the textile industry $(+b \leq 8.48)$ according to Santana et al. (2008). These same authors claim that maturity should be higher than $80 \%$ to maximize the absorption and retention of the dyes. Thus, even if cultivars show a differential response to this trait in the environments, all of them presented required values for suitable processing.

\section{Genetic diversity among cultivars in each environment}

To study genetic diversity, in each environment the Mahalanobis distance among cultivar pairs was estimated (Table 3 ). It was possible to observe a concordance in environment, being cultivars FM 910 and LD CV 02 the most divergent. Crossing these cultivars can be favorable because FM 910 shows favorable agronomic traits while LD CV 02 shows desirable technological traits (Table 2).

Table 3. Dissimilarity among 16 cotton cultivars evaluated in Sapezal (upper diagonal) and Lucas do Rio Verde (lower diagonal), based on the generalized Mahalanobis distance.

\begin{tabular}{l|c|c|c|c|c|c|c|c|c|c|c|c|c|c|c|c}
\hline Genotypes $^{1}$ & 1 & 2 & 3 & 4 & 5 & 6 & 7 & 8 & 9 & 10 & 11 & 12 & 13 & 14 & 15 & 16 \\
\hline 1 & 0.00 & 24.71 & 24.89 & 61.09 & 63.06 & 80.54 & 16.63 & 21.15 & 44.21 & 32.06 & 70.94 & 14.35 & 25.02 & 59.17 & 50.24 & 71.54 \\
\hline 2 & 23.06 & 0.00 & 19.81 & 29.46 & 29.36 & 50.12 & 18.86 & 24.71 & 22.62 & 57.59 & 32.14 & 26.51 & 26.29 & 35.99 & 40.87 & 57.16 \\
\hline 3 & 39.82 & 50.96 & 0.00 & 33.81 & 37.49 & 48.87 & 10.18 & 28.73 & 26.49 & 29.54 & 41.13 & 18.12 & 21.23 & 25.91 & 28.71 & 51.19 \\
\hline 4 & 37.89 & 23.78 & 77.31 & 0.00 & 20.99 & 63.01 & 31.48 & 52.17 & 21.10 & 52.34 & 47.49 & 65.83 & 62.01 & 38.59 & 52.91 & 75.29 \\
\hline 5 & 37.40 & 23.61 & 39.67 & 14.68 & 0.00 & 20.85 & 32.38 & 69.27 & 38.37 & 89.36 & 54.33 & 61.02 & 52.88 & 25.77 & 36.11 & 77.78 \\
\hline 6 & 57.71 & 43.12 & 61.05 & 28.24 & 15.22 & 0.00 & 48.33 & 98.02 & 69.72 & 121.07 & 82.68 & 65.64 & 58.95 & 41.82 & 40.27 & 95.21 \\
\hline 7 & 13.95 & 8.08 & 36.03 & 14.35 & 12.81 & 31.71 & 0.00 & 27.45 & 24.65 & 30.37 & 43.79 & 21.21 & 18.74 & 31.05 & 24.93 & 64.47 \\
\hline 8 & 15.65 & 23.88 & 25.94 & 49.31 & 38.50 & 62.20 & 15.76 & 0.00 & 21.01 & 43.78 & 30.88 & 48.50 & 32.53 & 37.43 & 37.25 & 31.14 \\
\hline 9 & 31.55 & 18.82 & 47.25 & 9.34 & 8.44 & 25.12 & 9.35 & 27.55 & 0.00 & 56.04 & 24.96 & 64.08 & 37.36 & 22.38 & 24.30 & 33.77 \\
\hline 10 & 26.47 & 38.27 & 53.60 & 66.80 & 65.00 & 99.43 & 40.30 & 29.88 & 58.05 & 0.00 & 90.18 & 38.89 & 63.43 & 84.12 & 81.87 & 96.40 \\
\hline 11 & 47.12 & 39.42 & 27.06 & 56.39 & 33.56 & 55.47 & 28.24 & 28.80 & 33.69 & 89.33 & 0.00 & 85.11 & 39.36 & 25.33 & 29.54 & 30.62 \\
\hline 12 & 19.92 & 29.59 & 85.47 & 25.37 & 46.44 & 66.39 & 24.67 & 48.84 & 37.57 & 33.93 & 93.60 & 0.00 & 32.98 & 70.46 & 66.86 & 103.28 \\
\hline 13 & 20.80 & 40.78 & 12.56 & 54.30 & 32.72 & 60.48 & 20.42 & 18.69 & 37.41 & 47.38 & 21.49 & 57.62 & 0.00 & 31.39 & 21.26 & 42.72 \\
\hline 14 & 48.47 & 45.03 & 30.61 & 33.21 & 13.54 & 29.96 & 26.86 & 39.19 & 16.59 & 82.30 & 17.34 & 76.00 & 26.08 & 0.00 & 8.47 & 25.20 \\
\hline 15 & 39.24 & 33.91 & 17.27 & 41.49 & 14.00 & 24.11 & 20.77 & 23.99 & 19.99 & 69.92 & 15.01 & 71.98 & 21.40 & 11.20 & 0.00 & 27.46 \\
\hline 16 & 46.22 & 50.27 & 33.90 & 51.29 & 31.46 & 49.86 & 27.89 & 28.26 & 29.88 & 91.89 & 11.67 & 90.57 & 21.53 & 14.80 & 19.68 & 0.00 \\
\hline
\end{tabular}

${ }^{1}$ Genotypes defined in Table 2.

Genetics and Molecular Research 16 (2): gmr16029628 
Exploring genetic diversity in this case, aims to direct heterotic crosses and to identify populations showing transgressive segregance in advanced generations. However, only after a performance analysis for the most important traits, cultivars can be considered as potential progenitors in the initial stage of a breeding program.

The cultivar pair formed by CNPA MT 042080 and CNPA MT 042088 presented reduced values of $\mathrm{D}_{\mathrm{ij}}{ }^{2}$ in both environments. This result was expected because these two cultivars are related and their crossing should be avoided to maintain genetic variability and guarantee selection gains. Genitors genetically related tend to share many alleles, and when a cross involving related individuals occurs, there is low complementary gene attributed to the low level of allelic heterozygosity (Cruz, 2012).

Correlation between dissimilarity matrices was 0.7112 , significant at $1 \%$ probability by the Mantel test, with critical level established after 5000 permutations (Figure 1). Despite GxE interaction not being significant for most of evaluated traits, some particular cultivar pairs presented differential performance, in terms of genetic diversity, when evaluated in different environments. According to the graphical dispersion (Figure 1), we can highlight the cultivar pair FM 993-BRS 293, which presented low diversity in Lucas do Rio Verde and high estimate in Sapezal, and the cultivar pairs BRS 286-FMT 701 and BRS 286-NUOPAL, which presented expressive diversity in Lucas do Rio Verde and low diversity in Sapezal. Factors such as fertilization, altitude, and rainfall regime may have influenced genotypic expression.

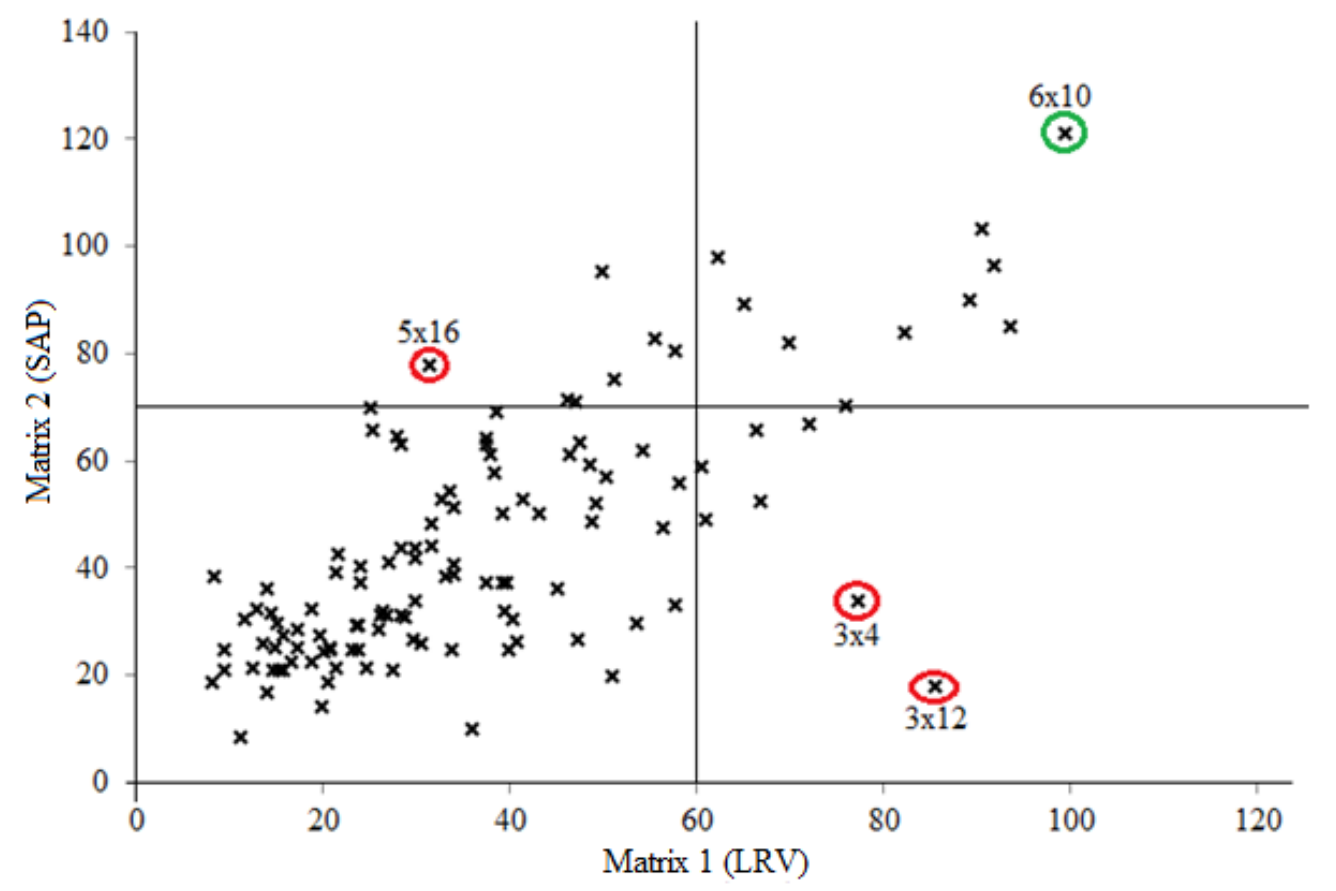

Figure 1. Dissimilarity dispersion expressed by generalized Mahalanobis distance among cotton cultivar pairs evaluated in Sapezal (SAP) and Lucas do Rio Verde (LRV).

Genetics and Molecular Research 16 (2): gmr16029628 
Even though correlation between matrices was considered high, the cultivars were grouped into six distinct clusters in Sapezal and five in Lucas do Rio Verde (Table 3). Cultivars LD CV 05, CNPA MT 04 2080, and CNPA MT 042088 were maintained in group I in both environments. Cultivars BRS 286 and CNPA MT 051245 were allocated in group II, while cultivar LD CV 02 remained alone regardless of environment. These results support the hypothesis that the cross between FM 910 and LD CV 02 is the most promising to generate potential segregant populations at both evaluated environments.

\section{Relative contribution of traits to genetic diversity in each environment}

The relative contribution of traits to divergence was obtained using the method proposed by Singh (1981) based on variance (Table 4). Variables with low magnitude, redundancy, and non-stability can be considered as unattractive in the genetic diversity study (Cruz et al., 2011). According to these criteria and considering both environments, lint percentage was the trait that most contributed to genetic diversity at $31.3 \%$, followed by average boll weight at $12.29 \%$.

Table 4. Clusters formed based on the Tocher optimization method considering 16 cotton cultivars evaluated in two environments in the State of Mato Grosso, Brazil.

\begin{tabular}{l|c|c}
\hline \multirow{2}{*}{ Groups } & \multicolumn{2}{|c}{ Genotypes $^{1}$} \\
\cline { 2 - 3 } & Lucas do Rio Verde (LRV) & Sapezal (SPH) \\
\hline 1 & $2,4,5,7,9,15,14$ & $9,11,14,15,16$ \\
\hline 2 & $3,8,11,13,16$ & $1,2,3,7,12,13$ \\
\hline 3 & 1,12 & 5,6 \\
\hline 4 & 10 & 4 \\
\hline 5 & 6 & 8 \\
\hline 6 & & 10 \\
\hline
\end{tabular}

${ }^{1}$ Genotypes defined in Table 2.

Although the lint percentage and average boll weight presented a higher discrimination capacity, traits such as seed cotton yield and fiber length cannot be excluded in cotton-breeding programs, because they represent the main objectives of farmers and textile industry (Table 5).

Table 5. Relative contribution of plant height ( $\mathrm{PH}, \mathrm{cm})$, average boll weight (ABW, g), lint percentage (LP, \%), seed cotton yield (SCY, kg/ha), fiber length (FL, mm), short fiber index (SFI, \%), fiber strength (FS, gf/tex), elongation (EL, \%), micronaire (MIC, $\mathrm{mg} /$ inches), reflectance (REF, \%), degree of yellowing $(\mathrm{B}+)$, spinning (SPI), and maturity of fibers (MAT, \%) according to Singh (1981) among 16 cotton cultivars evaluated in two environments in the State of Mato Grosso, Brazil.

\begin{tabular}{l|c|c|c|c}
\hline \multirow{2}{*}{ Variable } & \multicolumn{2}{|c|}{ Lucas do Rio Verde } & \multicolumn{2}{c}{ Sapezal } \\
\cline { 2 - 5 } & S.j. & $\%$ & S.j. & \% \\
\hline PH & 227.83 & 5.1 & 343.18 & 12.43 \\
\hline ABW & 542.27 & 12.15 & 1437.93 & 26.83 \\
\hline LP & 1595.99 & 35.77 & 392.96 & 7.33 \\
\hline SCY & 84.55 & 1.89 & 477.92 & 137.10 \\
\hline FL & 103.99 & 2.33 & 228.75 & 2.55 \\
\hline SFI & 142.13 & 3.18 & 493.33 & 4.26 \\
\hline EL & 2.80 & 0.06 & 189.75 & 9.20 \\
\hline MIC & 130.16 & 2.91 & 201.70 & 3.54 \\
\hline REF & 185.94 & 4.16 & 614.89 & 3.76 \\
\hline BPI & 409.00 & 9.16 & 17.90 & 11.47 \\
\hline MAT & 263.93 & 5.91 & 156.42 & 0.33 \\
\hline
\end{tabular}

S.j. - "S." is the measure of relative importance of each variable " $\mathrm{j."} \mathrm{for} \mathrm{the} \mathrm{study} \mathrm{of} \mathrm{genetic} \mathrm{diversity.}$

Genetics and Molecular Research 16 (2): gmr16029628 


\section{REFERENCES}

Araújo WP, Pereira JR, Almeida ESAB, Araújo VL, et al. (2013). Componentes da fibra de cultivares de algodoeiro herbáceo sob lâminas de água. Rev. Ed. Agric. Sup. 28: 78-81.

Carvalho LP, Barroso PAV, Santos JAT and Alves HS (2005). Seleção massal e porcentagem de fibra em cultivar de algodoeiro colorido. Pesqui. Agropecu. Bras. 40: 895-898. http://dx.doi.org/10.1590/S0100-204X2005000900009

Carvalho LP, Farias FJC and Rodrigues JIS (2015a). Selection for increased fiber length in cotton progenies from Acala and Non-Acala types. Crop Sci. 55: 1-7.

Carvalho LP, Farias FJC, Morello CL, Rodrigues JIS, et al. (2015b). Agronomic and technical fibers traits in elite genotypes of cotton herbaceous. Afr. J. Agric. Res. 10: 4882-4887. http://dx.doi.org/10.5897/AJAR2015.10515

CONAB - Companhia Nacional de Abastecimento (2015). Acompanhamento de Safra Brasileira: grãos, safra 2013/2014, $12^{\circ}$ levantamento, setembro/2015. Available at [http://www.conab.gov.br/OlalaCMS/uploads/ arquivos/14_09_10_14_35_09_boletim_graos_setembro_2014.pdf]. Accessed abril 19, 2016.

Cruz CD (2012). Princípios de Genética Quantitativa. 1a ed. Editora UFV, Viçosa.

Cruz CD (2013). GENES - a software package for analysis in experimental statistics and quantitative genetics. Acta Sci. Agron. 35: 271-276 http://dx.doi.org/10.4025/actasciagron.v35i3.21251.

Cruz CD, Ferreira MF and Pessoni LA (2011). Biometria Aplicada ao estudo da diversidade genética. 1a ed. Suprema, Visconde do Rio Branco.

Farias FJC, Carvalho LP, Silva Filho JL and Teodoro PE (2016). Correlations and path analysis among agronomic and technological traits of upland cotton. Genet. Mol. Res. 15: gmr. 15038239.

Freitas RJ, Leandro WM and Carvalho MCS (2007). Efeito da adubação potássica via solo e foliar sobre a produção e a qualidade da fibra em algodoeiro (Gossypium hirsutum L.). Pesqui. Agropecu. Bras. 37: 106-112.

Hinze LL, Gazave E, Gore MA, Fang DD, et al. (2016). Genetic Diversity of the Two Commercial Tetraploid Cotton Species in the Gossypium Diversity Reference Set. J. Hered. 107: 274-286. http://dx.doi.org/10.1093/jhered/esw004

Pimentel-Gomes F (2009). Curso de Estatística Experimental. 15a ed. Fealq, São Paulo.

Santana JCF, Wanderley MJR, Beltrão NEM, Azevedo DMP, et al. (2008). Características da fibra e do fio do algodão: análise e interpretação dos resultados. In: O agronegócio do algodão no Brasil (Beltrão NEM and Azevedo DMP, eds.). Embrapa Informação Tecnológica, Brasília.

Silva RP, Ferreira IC and Cassia MT (2011). Perdas na colheita mecanizada de algodão. Sci. Agropec. 2: 07-12.

Singh D (1981). The relative importance of characters affecting genetic divergence. Indian J. Genet. Plant Breed. 41: 237-245.

Tyagi P, Gore MA, Bowman DT, Campbell BT, et al. (2014). Genetic diversity and population structure in the US Upland cotton (Gossypium hirsutum L.). Theor. Appl. Genet. 127: 283-295. http://dx.doi.org/10.1007/s00122-013-2217-3

Genetics and Molecular Research 16 (2): gmr16029628 